\title{
Effect of Preservative and Storage Temperatures on Total Soluble Solids and Antioxidant Activity of Carrot Based RTS Beverages
}

\author{
Laxmi Pandey $^{1 *}$, Renu Mogra ${ }^{1}$ and Arun Kumar ${ }^{2}$ \\ ${ }^{1}$ Department of Food Science and Nutrition, College of Community and Applied Science, \\ ${ }^{2}$ Department of Dairy and Food Chemistry, College of Dairy and Food Technology, \\ Maharana Pratap University of Agriculture and Technology, Udaipur, Rajasthan, India \\ *Corresponding author
}

\section{A B S T R A C T}

The study was conducted to develop carrot based antioxidant rich RTS beverages with and without added preservative stored at different temperatures (refrigeration, ambient and accelerated). The antioxidant rich RTS beverages were developed by using carrot, beetroot, aonla and ginger juice blends in the different proportion i.e. 100:0:0:0, 80:15:2.5:2.5 (T1), 70:25:2.5:2.5 (T2), 60:35:2.5:2.5 (T3) and 50:45:2.5:2.5 (T4) respectively, adjusted $20 \%$ juice, $15 \%$ TSS and $0.3 \%$ acidity at the time of preparation.

Keywords

Carrot, RTS

beverages,

Preservative, TSS,

Antioxidant activity

Article Info

Accepted:

15 October 2020

Available Online:

10 November 2020

The carrot based RTS beverages were assessed for the quality attributes at zero day and stored to assess the antioxidant stability of RTS beverages during storage. The RTS beverages treated with and without preservative were evaluated for chemical properties (TSS, pH, acidity and total antioxidant activity) at the interval of 15 days up to 3 months of storage. It was observed that TSS and acidity were increased slightly but nonsignificantly (from 14.48 to $14.49^{\circ}$ Brix) and (from 14.48 to $14.55^{\circ}$ Brix), respectively of treatments containing preservative and no preservatives during storage at refrigeration temperature. At ambient temperature, the carrot based RTS beverages resulted nonsignificant increase in TSS (from 14.48 to 14.74 Brix) and (from 14.48 to 14.75 Brix), respectively of treatments containing preservative and of treatments having no preservatives at the end of storage. At refrigeration, antioxidant activity was significantly $(\mathrm{P} \leq 0.05)$ decreased from 39.50 to $32.55 \%$ and 39.04 to $30.60 \%$ in RTS beverages containing preservative and without preservatives, respectively whereas from 39.50 to $30.77 \%$ and 39.04 to $27.47 \%$, respectively at ambient temperature during three months of storage. It was inferred that chemical attributes of the RTS beverages stored at accelerated temperature were destroyed within 15 days of storage and are not safe for the consumption. The RTS beverages were found most acceptable chemically when stored at refrigeration temperature as compared to ambient temperature and are recommended for commercial production.

\section{Introduction}

India is bestowed with adverse agro climatic conditions, therefore here is a wide variety of fruits and vegetables are produced. It ranks second in fruits and vegetables production in the world, after China. (National Horticulture Database (NHD) published by National 
Horticulture Board, during 2012-2013). Consumption of fruit and vegetables is recommended as part of a healthy diet as these are rich sources of phytochemicals such as carotenoids, polyphenols, vitamins and minerals, besides presenting complex carbohydrates and fibres (Heber, 2004). Fruits and vegetables like mango, pine apple, guava, lemon, grape, apple, litchi, jamun, watermelon, orange, carrot, sugar beet etc. and their blends are used for the preparation of RTS beverages with or without addition of spices like ginger, cardamom, cumin, mint, black pepper etc. these beverages are far more superior then the synthetic carbonated drinks in the terms of quality.

Antioxidants help to combat free radicals generated in body. These free radicals accelerate hyper pigmentation syndrome, heart disease, stroke, atherosclerosis, diabetes and cancer. Fruits and vegetables, apart from being good sources of vitamins, minerals, and fibre, are also rich sources of potentially bioactive compounds known as phytochemical. Among the phytochemicals, antioxidants are abundant that prevent some of the processes involved in the development of cancer, and cardiovascular disease (Denny and Buttriss, 2007).

Carrot (Daucus carota L.) is one of the most important seasonal root vegetables of Apiaceae (Umbelliferae) family grown throughout the world. It is an inexpensive and highly nutritious vegetable. China is the largest producing country of carrot in the world. In India, the carrot is produced 10.93 lakh tones annually from an area of 68,000 ha during 2014-15. Haryana is the leading producer of carrot with 2.51 lakh tonnes in an area of 18000 ha, followed by Tamil Nadu, Punjab, Karnataka and Uttar Pradesh (NHB, 2016). Fresh carrot on an average contains moisture $86 \%$, carbohydrates $10.6 \%$, protein $0.9 \%$, fat $0.18 \%$, crude fiber $1.2 \%$ and minerals $\quad 1.1 \% \quad$ (Istridula, 2011). Its carbohydrate contains simple sugars, predominantly sucrose, glucose and fructose with small amount of starch. It also contains Vitamin C (5.9 mg/100g), Vitamin $B_{1}(0.07$ $\mathrm{mg} / 100 \mathrm{~g})$, Vitamin $\mathrm{B}_{2} \quad(0.06 \mathrm{mg} / 100 \mathrm{~g})$, Vitamin $\mathrm{B}_{3}(0.93 \mathrm{mg} / 100 \mathrm{~g})$, Vitamin $\mathrm{B}_{6}$ $(0.14 \mathrm{mg} / 100 \mathrm{~g})$ and $\beta$-carotene $(8285$ $\mu \mathrm{g} / 100 \mathrm{~g}$ ) (USDA, 2012).Carrot is rich in antioxidants like $\alpha$-carotene, $\beta$-carotene, flavonoids and phenolic derivatives, which have anticarcinogenic activities, reduce inflammatory insult, and modulate immune response (Zhang and Hamauzuet, 2004; Dias, 2012).

Beetroot (Beta vulgaris) is botanically classified as an herbaceous biennial from Chenopodiaceae family and has several varieties with bulb colours ranging from yellow to red. Beetroot contains 87.4, 1.35, $0.3,1.9,2.56$ and $1.4 \%$ of moisture, protein, fat, dietary fiber, total fiber, and mineral contents respectively (Arora et al., 2019). Beetroots may prevent heart diseases due to their protective antioxidant activity and are one of the richest dietary sources of antioxidants. These have an alkaline $\mathrm{pH}$ from 7.5 to 8.0 and has been acclaimed for its health benefits and has disease fighting antioxidant potential (Singh and Hatan, 2013). The beetroot juice is used as a natural remedy for sexual weakness and to expel kidney and bladder stones.

The therapeutic use of beetroot includes its antitumor, carminative, emmenagogue and hemostatic and renal protective properties (Vali et al., 2007).Consumption of natural produce beetroot juice which is rich in antioxidant compounds may help to redress the balance between Reactive oxygen and nitrogen species(RONS) production and endogenous protection when the body is under oxidative stress (Peter et al., 2011). 
Aonla (Emblica officinalis) belongs to family Euphorbiaceae. It is one of the most important minor fruits of Indian origin and is predicted to be the fruit of 21st century. Aonla fruits are round, ribbed and pale green in colour with segmented body. Aonla cultivars viz., Chakaiya, Krishna, Kanchan, Banarasi, Narendra-7, Narendra-10, Balwant Bold and Francis are grown throughout the country in different agroclimatic conditions (Yadav and Yadav, 2010).

The fruit is acrid, cooling, refrigerant, diuretic and laxative. It is claimed to be the second richest source of natural vitamin C (600-900 $\mathrm{mg} / 100 \mathrm{~g}$ ) after Barbadose cherry (Pokharkar, 2005).

Ginger (Zingiber officinale Roscoe) is a flowering plant which belongs to the family Zingiberaceae whose rhizome, ginger root or simply ginger is widely used as a spice or a folk medicine. Ginger juice has anti-bacterial and anti-fungal properties. It is widely claimed as a Stomachic, aromatic, carminative, aphrodisiacs, diaphoretic, antiemetic, allergic rhinitis and gastric stimulant and for treating migraine headache (Prasad et al., 2012).

For improving taste, aroma, palatability and nutritive value, carrot juice was blended with highly nutritive fruit and vegetable juices namely beetroot, aonla with spice extracts like ginger.

All these fruit and vegetables are greatly valued for their refreshing juice with nutritional and medicinal properties. Therefore, the investigation was aimed at standardizing processing temperatures for thermal processing, chemical preservatives and blending ratio of carrot, beetroot, aonla and ginger juice to study chemical parameters during storage.

\section{Materials and Methods}

\section{Locale of the study}

The present investigation entitled "Development and quality evaluation of antioxidant rich ready-to-serve beverages" was conducted at Department of Food Science and Nutrition, College of Community and Applied Sciences, MPUAT, Udaipur, Rajasthan

\section{Procurement of materials}

For the preparation of antioxidant rich readyto-serve (RTS) beverages, antioxidant rich fruit, vegetables and spices viz. carrot, beetroot, aonla, ginger, jamun and lemon were purchased in bulk from the local market of Udaipur city. The fruits of uniform size, free from any injury and disease were selected. On the basis of rich antioxidant profile of different fruits, vegetables and spices from studied reported literature, six seasonal fruits, vegetable and spices were selected for the preparation of antioxidant rich ready-to-serve (RTS) beverages for their quality evaluation.

\section{Processing of carrot, beetroot, ginger and aonla for juice extraction}

Healthy and disease free fresh red carrot, beetroot and ginger were sorted separately, washed thoroughly under running tap water and peeled with the help of stainless steel knife to remove adhered soil particles and small roots attached to their skin. Carrot, beetroot and ginger juices were extracted separately by using electric juice extractor. The extracted juices were filtered through four layer muslin cloth to get clear juice. The fresh extracted juices were used for preparation of carrot based ready-to-serve (RTS) beverages. 


\section{Carrot based ready-to-serve beverages}

Antioxidant rich carrot based ready-to-serve beverages were prepared by blending the juices in four different ratios of carrot, beetroot, aonla and ginger juices 80:15:2.5:2.5 $\quad\left(\mathrm{T}_{1}\right), \quad$ 70:25:2.5:2.5 $\quad\left(\mathrm{T}_{2}\right)$, 60:35:2.5:2.5 $\left(\mathrm{T}_{3}\right)$ and 50:45:2.5:2.5 $\left(\mathrm{T}_{4}\right)$ respectively, adjusted $20 \%$ juice, $15 \%$ TSS and $0.3 \%$ acidity at the time of preparation in all the formulated blends, while pure carrot ready-to-serve beverage having the ratio 100:0:0:0 of carrot, beetroot, aonla and ginger and treated as control $\left(\mathrm{T}_{0}\right)$.

The volume of the final product was maintained by adding potable water to each formulation in each replication. A calculated amount of sugar was added in the RTS beverages. The acidity was maintained to $0.3 \%$ in the final product by the addition of required amount of citric acid (Table.1). The developed carrot based RTS beverages were again filtered through a muslin cloth to obtain a beverage of uniform consistency. The developed carrot based RTS beverages were pasteurized at $90^{\circ} \mathrm{C}$ for $30 \mathrm{sec}$. and cooled at room temperature.

Sensory evaluation of carrot and jamun based ready-to-serve beverages

A panel of ten judges comprising of the staff and research scholars were randomly selected from the Department of Food Science and Nutrition, College of Community and Applied Sciences, MPUAT, Udaipur for the evaluation of acceptability of the ready-to serve (RTS) beverages developed during the study. The overall acceptability was measured on 9 point Hedonic Scale by 10 panel members. Coded samples were presented to panellist in separate chambers or places to get unbiased judgments with score cards for evaluating the sensory characteristics.
Shelf life Assessment of antioxidant rich ready-to-serve beverages

On the basis of different formulation ratios and sensory evaluation of four types of carrot based ready-to-serve viz. CABG1 $\left(\mathrm{T}_{1}\right)$, CABG2 $\left(\mathrm{T}_{2}\right), \mathrm{CABG} 3\left(\mathrm{~T}_{3}\right), \mathrm{CABG} 4\left(\mathrm{~T}_{4}\right)$, two most acceptable ratios $\left(\mathrm{T}_{1}\right),\left(\mathrm{T}_{4}\right)$ and control were selected for further processing treatments and assessment of chemical properties under shelf life studies.

\section{Chemical properties}

\section{Total Soluble Solids (TSS)}

The total soluble solids (TSS) of the fruits were determined by the standard method (AOAC, 2012). TSS ( ${ }^{\circ}$ Brix) of the juice was found using hand refractometer by placing a drop of the juice on the refractometer prism before taking the reading.

The instrument was calibrated and reading was taken accurately by putting a minute quantity offresh extracted juice and RTS beverages. Data was expressed as ${ }^{\circ}$ Brix after temperature correction.

\section{Total antioxidant activity}

The percentage of 2, 2-diphenyl-1picrylhydrazyl (DPPH) radical scavenging activities of fruit pulp/juices and RTS drink was determined by the slight modification of the spectrophotometric method as suggested by Shimada et al., (1992).

\section{Preparation of dye}

To $25 \mathrm{mg}$ DPPH dye, $10 \mathrm{ml}$ of methanol was added, and vigorous shaken, till the dye got dissolved. $1 \mathrm{ml}$ of this solution was taken in volumetric flask and volume was made up to $100 \mathrm{ml}$ with methanol (working solution). 


\section{Extraction}

$500 \mu \mathrm{l}$ of sample was macerated in $10 \mathrm{ml}$ methanol and centrifuged at $4000 \mathrm{rpm}$. Supernatant was used to measure the antioxidant activity.

\section{Estimation}

The hydrogen atom or electron donation abilities of fruit juice/processed product were measured by the bleaching of red/purple colour methanol solution of stable 2, 2dipheny1-1-picrylhydrazyl (DPPH). Briefly, $100 \mu \mathrm{l}$ of sample or $100 \mu \mathrm{l}$ of methanol (control) were added to $3 \mathrm{ml}$ of working solution of DPPH and incubated for $30 \mathrm{~min}$ at $25-30^{\circ} \mathrm{C}$ in water bath. The absorbance of the sample and control was measured with spectrophotometer at $517 \mathrm{~nm}$ using methanol as blank. Lower absorbance of reaction mixture than that of control indicated higher free radical scavenging activity'antioxidant activity. The capabilities to scavenge the DPPH radicals, was calculated using following formula and expressed in \% scavenging of DPPH.

Antioxidant activity (\% scavenging of DPPH) $=\frac{A_{0}-A_{1}}{A_{0}} \times 100$

Where, $\mathrm{A}_{0}=$ Absorbance of blank

$\mathrm{A}_{1}=$ Absorbance of sample

\section{Statistical analysis}

The data generated during experimentation were statistically analysed using standard procedure for analysis (Three way anova) of completely randomized block design as per the method suggested by Panse and Sukhtam (1985). The standard errors (SE) and critical differences (CD) at 5\% level of significance were worked out for comparison of treatments and presented in the tables.

\section{Results and Discussion}

The data revealed changes in chemical properties of antioxidant rich carrot based RTS beverages due to the effect of thermal processing with or without preservative and storage period, stored at refrigeration and ambient temperature.

\section{Total soluble solids}

The data revealed that the TSS increased slightly but showed significant differences among different treatments of carrot based RTS beverages on further storage up to three months. At 0 day, the carrot based RTS beverages recorded minimum increase in TSS (from 14.48 to $14.49^{\circ}$ Brix) and (from 14.48 to $\left.14.55^{\circ} \mathrm{Brix}\right)$ of treatments containing preservative and no preservative and showed non-significant $(\mathrm{P} \leq 0.05)$ differences among treatments treated with or without preservatives during storage. The two way interaction $(\mathrm{A} \times \mathrm{B})$ between with or without preservative and storage period was found to be non-significant. Irrespective of with or without preservative mean, among all the treatments, the TSS of blended carrot based RTS beverages $\left(T_{1}\right.$ and $\left.T_{4}\right)$ were at par with each other while TSS was slightly but significantly increased in $100 \%$ carrot based RTS beverages $\left(T_{0}\right)$ up to three months of storage. At refrigeration temperature, the TSS were affected by blending ratio and storage period however the mean value of TSS being at par with each other for before and after bottling among three types $\left(\mathrm{T}_{0}, \mathrm{~T}_{1}, \mathrm{~T}_{4}\right)$ of carrot based RTS beverages during storage. The interaction $(B \times C)$ between storage period and thermally processed RTS beverages was found non- significant. The TSS of carrot based RTS beverages was not significantly affected by with or without preservative during storages and the two way interaction $(A \times C)$ between with or without preservative and thermally processed RTS beverages was 
found to be non-significant. The various interactions $\mathrm{A} \times \mathrm{B}, \mathrm{B} \times \mathrm{C}, \mathrm{A} \times \mathrm{C}, \mathrm{A} \times \mathrm{B} \times \mathrm{C}$ were found to be non-significant at refrigeration temperature.

At ambient temperature, the results showed that the TSS increased slightly but showed significant differences among different treatments of carrot based RTS beverages up to three months of storage. At 0 day, the carrot based RTS beverages recorded minimum increase in TSS (from 14.48 to $14.74^{\circ}$ Brix) and (from 14.48 to $14.75^{\circ}$ Brix) of treatments containing preservative and no preservatives and showed significant $(\mathrm{P} \leq 0.05)$ differences among treatments treated with or without preservatives but not significantly $(\mathrm{P} \leq 0.05)$ affected by storage. The two way interaction $(\mathrm{A} \times \mathrm{B})$ between with or without preservative and storage period was found to be non-significant. Irrespective of with or without preservative mean, among all the treatments, the TSS of carrot based RTS beverages was highly increased in RTS beverages $\left(T_{0}\right)$ while blended RTS beverages $\left(\mathrm{T}_{1}\right.$ and $\left.\mathrm{T}_{4}\right)$ showed slight increase during storage. The TSS was affected by blending ratio and storage period however the mean value of TSS was higher in before bottling as compare to after bottling among carrot based RTS beverages during storage. The interaction $(\mathrm{B} \times \mathrm{C})$ between storage period and thermally processed RTS beverages was found non-significant. The two way interaction $(\mathrm{A} \times \mathrm{C})$ between with or without preservative and thermally processed RTS beverages was found to be $(\mathrm{P} \leq 0.05)$ significant. The various interactions $\mathrm{A} \times \mathrm{B}$, $\mathrm{B} \times \mathrm{C}, \mathrm{A} \times \mathrm{B} \times \mathrm{C}$ except $\mathrm{A} \times \mathrm{C}$ were found to be non-significant at ambient temperature.

The TSS increased with gradual passage of storage period (Table 2.) which might be due to hydrolysis of polysaccharides into monosaccharide and oligosaccharides or consumption of sugars as a result of onset of fermentation. Jan and Masih (2012) found an increasing trend in total soluble solids during storage at ambient and low temperature in lime - aonla and mango-pineapple spiced RTS (Ready-to-Serve) beverages and Jumde et al., (2015) in juice blends.

In the present investigation, addition of preservatives did not affect significantly the TSS of RTS beverages at refrigeration while significantly $(\mathrm{P} \leq 0.05)$ influenced the RTS beverages containing no preservatives at ambient temperature. Similarly Arora et al., (2019) found that addition of preservative did not significantly affect the TSS in pure banana RTS drinks as compare to without preservatives.

Table.1 Formulations of antioxidant rich carrot based ready-to-serve beverages

\begin{tabular}{|c|c|c|c|c|c|c|c|c|}
\hline \multirow{2}{*}{$\begin{array}{l}\text { Sr. } \\
\text { no. }\end{array}$} & \multirow{2}{*}{$\begin{array}{c}\text { Treatment } \\
\text { symbols }\end{array}$} & \multicolumn{4}{|c|}{ Blending of Juices (\%) } & \multirow{2}{*}{$\begin{array}{l}\text { Sugar } \\
\text { (g) }\end{array}$} & \multirow{2}{*}{$\begin{array}{c}\text { Citric } \\
\text { acid (g) }\end{array}$} & \multirow{2}{*}{$\begin{array}{c}\text { Sodium } \\
\text { benzoate }(g)\end{array}$} \\
\hline & & Carrot & Beetroot & Aonla & Ginger & & & \\
\hline 1. & Control $\left(\mathrm{T}_{0}\right)$ & 100 & 0 & 0 & 0 & 11.0 & 0.27 & 0.05 \\
\hline 2. & CBAG $1\left(\mathrm{~T}_{1}\right)$ & 80 & 15 & 2.5 & 2.5 & 11.0 & 0.27 & 0.05 \\
\hline 3. & CBAG $2\left(\mathrm{~T}_{2}\right)$ & 70 & 25 & 2.5 & 2.5 & 11.0 & 0.27 & 0.05 \\
\hline 4. & CBAG $3\left(\mathrm{~T}_{3}\right)$ & 60 & 35 & 2.5 & 2.5 & 11.0 & 0.27 & 0.05 \\
\hline 5. & CBAG $4\left(\mathrm{~T}_{4}\right)$ & 50 & 45 & 2.5 & 2.5 & 11.0 & 0.27 & 0.05 \\
\hline
\end{tabular}

CBAG- Carrot, Beetroot, Aonla, Ginger 
Table.2 Effect of different treatments (thermal processing with/without preservative) and storage periods on total soluble solids $\left({ }^{\circ}\right.$ Brix) of carrot based RTS beverages stored at refrigeration temperature

\begin{tabular}{|c|c|c|c|c|c|c|c|c|c|c|c|c|c|c|}
\hline \multirow{3}{*}{$\begin{array}{c}\text { Storage } \\
\text { period } \\
\text { (Days) }\end{array}$} & \multicolumn{14}{|c|}{ Total soluble solids ( ${ }^{\circ}$ Brix) } \\
\hline & \multicolumn{7}{|c|}{ With preservative } & \multicolumn{7}{|c|}{ Without Preservative } \\
\hline & $\mathrm{T}_{0}: \mathrm{BB}$ & $\mathrm{T}_{0}: \mathrm{AB}$ & $\mathrm{T}_{1}: \mathrm{BB}$ & $\mathrm{T}_{1}: \mathrm{AB}$ & $T_{4}: B B$ & $\mathbf{T}_{4}: \mathrm{AB}$ & Mean & $\mathrm{T}_{0}: \mathrm{BB}$ & $\mathrm{T}_{0}: \mathrm{AB}$ & $\mathbf{T}_{1}: \mathrm{BB}$ & $\mathrm{T}_{1}: \mathrm{AB}$ & $\mathbf{T}_{4}: \mathbf{B B}$ & $\mathrm{T}_{4}: \mathrm{AB}$ & Mean \\
\hline $\mathbf{0}$ & 13.03 & 13.03 & 14.13 & 14.13 & 16.27 & 16.27 & 14.48 & 13.04 & 13.04 & 14.13 & 14.13 & 16.27 & 16.27 & 14.48 \\
\hline 15 & 13.04 & 13.04 & 14.14 & 14.13 & 16.28 & 16.27 & 14.48 & 13.05 & 13.05 & 14.14 & 14.14 & 16.28 & 16.28 & 14.49 \\
\hline 30 & 13.05 & 13.05 & 14.15 & 14.14 & 16.28 & 16.28 & 14.49 & 13.07 & 13.06 & 14.15 & 14.15 & 16.30 & 16.29 & 14.50 \\
\hline 45 & 13.05 & 13.05 & 14.15 & 14.15 & 16.28 & 16.28 & 14.49 & 1308 & 13.07 & 14.17 & 14.16 & 16.31 & 16.30 & 14.52 \\
\hline 60 & 13.06 & 13.05 & 14.15 & 14.15 & 16.29 & 16.28 & 14.50 & 13.10 & 13.09 & 14.18 & 14.17 & 16.32 & 16.31 & 14.53 \\
\hline 75 & 13.06 & 13.06 & 14.16 & 14.15 & 16.30 & 16.29 & 14.50 & 13.11 & 13.10 & 14.19 & 14.18 & 16.33 & 16.32 & 14.54 \\
\hline 90 & 13.07 & 13.07 & 14.16 & 14.16 & 16.30 & 16.30 & 14.51 & 13.13 & 13.12 & 14.20 & 14.19 & 16.35 & 16.34 & 14.55 \\
\hline Mean & 13.05 & 13.05 & 14.15 & 14.15 & 16.29 & 16.28 & 14.49 & 13.08 & 13.08 & 14.17 & 14.16 & 16.31 & 16.30 & 14.52 \\
\hline \multirow{3}{*}{$\begin{array}{l}\text { Storage } \\
\text { period } \\
\text { (Days) }\end{array}$} & \multicolumn{14}{|c|}{ Thermally processed RTS beverages } \\
\hline & \multirow{2}{*}{\multicolumn{2}{|c|}{$\begin{array}{c}\text { Before bottling } \\
\mathrm{T}_{0}: \mathrm{BB}\end{array}$}} & \multirow{2}{*}{\multicolumn{2}{|c|}{$\begin{array}{c}\text { After bottling } \\
\mathbf{T}_{0}: \mathrm{AB}\end{array}$}} & \multirow{2}{*}{\multicolumn{2}{|c|}{$\begin{array}{c}\text { Before bottling } \\
\mathbf{T}_{1}: \mathbf{B B}\end{array}$}} & \multirow{2}{*}{\multicolumn{2}{|c|}{$\begin{array}{c}\text { After bottling } \\
\mathbf{T}_{1}: \mathrm{AB}\end{array}$}} & \multirow{2}{*}{\multicolumn{2}{|c|}{$\begin{array}{c}\text { Before bottling } \\
\mathbf{T}_{4}: \mathbf{B B}\end{array}$}} & \multirow{2}{*}{\multicolumn{2}{|c|}{$\begin{array}{c}\text { After bottling } \\
\mathrm{T}_{4}: \mathrm{AB}\end{array}$}} & \multirow{2}{*}{\multicolumn{2}{|c|}{ Mean }} \\
\hline & & & & & & & & & & & & & & \\
\hline 0 & \multicolumn{2}{|c|}{13.03} & \multicolumn{2}{|c|}{13.03} & \multicolumn{2}{|c|}{14.13} & \multicolumn{2}{|c|}{14.13} & \multicolumn{2}{|c|}{16.27} & \multicolumn{2}{|c|}{16.27} & \multicolumn{2}{|c|}{14.48} \\
\hline 15 & \multicolumn{2}{|c|}{13.05} & \multicolumn{2}{|c|}{13.04} & \multicolumn{2}{|c|}{14.14} & \multicolumn{2}{|c|}{14.14} & \multicolumn{2}{|c|}{16.28} & \multicolumn{2}{|c|}{16.28} & \multicolumn{2}{|c|}{14.49} \\
\hline 30 & \multicolumn{2}{|c|}{13.06} & \multicolumn{2}{|c|}{13.05} & & .15 & 14 & & 16. & & & & & 50 \\
\hline 45 & 13. & & & 06 & & .16 & 14 & & 16. & & & & 14 & 50 \\
\hline 60 & 13. & & & 07 & & .17 & 14 & & 16. & & & & & 51 \\
\hline 75 & 13. & & & 08 & & .17 & 14 & & 16. & & & & & 52 \\
\hline 90 & 13. & & & 10 & & .18 & 14 & & 16. & & & & & 53 \\
\hline Mean & 13. & & & .06 & & .16 & 14 & & 16. & & & & & \\
\hline Factors & $\begin{array}{r}\text { With/Y } \\
\text { preserva }\end{array}$ & $\begin{array}{l}\text { hout } \\
\text { ve }(A)\end{array}$ & Storage & period & $\begin{array}{l}\text { The } \\
\text { proces }\end{array}$ & $\begin{array}{l}\text { rmal } \\
\operatorname{sing}(C)\end{array}$ & A & & $A x$ & & & & $A \times I$ & $3 \times C$ \\
\hline $\begin{array}{c}\mathrm{CD}(\mathrm{P} \leq 0.0 \\
5)\end{array}$ & $\mathrm{N}$ & & & S & & 32 & $\mathrm{~N}$ & & $\mathrm{~N}$ & & & & & S \\
\hline $\mathrm{SE} \pm \mathrm{m}$ & 0.0 & & $0 .($ & 12 & $0 .($ & 011 & 0.0 & & 0.0 & & & & & 42 \\
\hline $\begin{array}{l}\mathrm{T}_{0}: \mathrm{BB}-(100 \% \mathrm{c} \\
\mathrm{T}_{4}: \mathrm{BB} \text { - (carrot- }\end{array}$ & root-aonla- & er, 50:45: & $5: 2.5)$, the & $\begin{array}{l}\text { ttling), } \\
\text { mal pro }\end{array}$ & 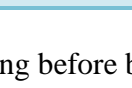 & $\mathrm{g},{ }^{\mathrm{T}}$ & ( & 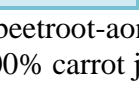 & erme & $15-5$ & & & & \\
\hline
\end{tabular}


Table.3 Effect of different treatments (thermal processing with/without preservative) and storage periods on total soluble solids (Brix) of carrot based RTS beverages stored at ambient temperature

\begin{tabular}{|c|c|c|c|c|c|c|c|c|c|c|c|c|c|c|}
\hline \multirow{3}{*}{$\begin{array}{c}\text { Storage } \\
\text { period } \\
\text { (Days) }\end{array}$} & \multicolumn{14}{|c|}{ Total soluble solids $\left({ }^{\circ}\right.$ Brix $)$} \\
\hline & \multicolumn{7}{|c|}{ With preservative } & \multicolumn{7}{|c|}{ Without Preservative } \\
\hline & $\mathbf{T}_{0}: \mathbf{B B}$ & $\mathrm{T}_{0}: \mathrm{AB}$ & $\mathbf{T}_{1}: \mathbf{B B}$ & $T_{1}: A B$ & $\mathbf{T}_{4}: \mathbf{B B}$ & $\mathrm{T}_{4}: \mathrm{AB}$ & Mean & $\mathbf{T}_{0}: \mathbf{B B}$ & $\mathrm{T}_{0}: \mathrm{AB}$ & $\mathbf{T}_{1}: \mathbf{B B}$ & $\mathrm{T}_{1}: \mathrm{AB}$ & $\mathrm{T}_{4}: \mathrm{BB}$ & $\mathrm{T}_{4}: \mathrm{AB}$ & Mean \\
\hline 0 & 13.03 & 13.03 & 14.13 & 14.13 & 16.27 & 16.27 & 14.48 & 13.04 & 13.04 & 14.13 & 14.13 & 16.27 & 16.27 & 14.48 \\
\hline 15 & 13.09 & 13.08 & 14.17 & 14.17 & 16.31 & 16.31 & 14.52 & 13.12 & 13.10 & 14.19 & 14.18 & 16.33 & 16.32 & 14.54 \\
\hline 30 & 13.14 & 13.13 & 14.21 & 14.21 & 16.34 & 16.33 & 14.56 & 13.18 & 13.16 & 14.23 & 14.22 & 16.37 & 16.37 & 14.59 \\
\hline 45 & 13.20 & 13.18 & 14.25 & 14.24 & 16.38 & 16.37 & 14.60 & 13.24 & 13.21 & 14.26 & 14.26 & 16.42 & 16.41 & 14.63 \\
\hline 60 & 13.24 & 13.22 & 14.30 & 14.29 & 16.42 & 16.41 & 14.65 & 13.30 & 13.27 & 14.30 & 14.29 & 16.45 & 16.44 & 14.67 \\
\hline 75 & 13.30 & 13.28 & 14.34 & 14.33 & 16.47 & 16.46 & 14.70 & 13.34 & 13.31 & 14.34 & 14.33 & 16.48 & 16.47 & 14.71 \\
\hline 90 & 13.34 & 13.33 & 14.39 & 14.38 & 16.51 & 16.50 & 14.74 & 13.38 & 13.36 & 14.37 & 14.36 & 16.53 & 16.51 & 14.75 \\
\hline Mean & 13.19 & 13.18 & 14.26 & 14.25 & 16.39 & 16.38 & 14.61 & 13.23 & 13.21 & 14.26 & 14.25 & 16.41 & 16.40 & 14.63 \\
\hline \multirow{3}{*}{$\begin{array}{c}\text { Storage } \\
\text { period } \\
\text { (Days) }\end{array}$} & \multicolumn{14}{|c|}{ Thermally processed RTS beverages } \\
\hline & \multirow{2}{*}{\multicolumn{2}{|c|}{$\begin{array}{c}\text { Before bottling } \\
\mathrm{T}_{0}: \mathrm{BB}\end{array}$}} & \multirow{2}{*}{\multicolumn{2}{|c|}{$\begin{array}{c}\text { After bottling } \\
\mathrm{T}_{0}: \mathrm{AB}\end{array}$}} & \multirow{2}{*}{\multicolumn{2}{|c|}{$\begin{array}{c}\text { Before bottling } \\
\mathrm{T}_{1}: \mathrm{BB}\end{array}$}} & \multirow{2}{*}{\multicolumn{2}{|c|}{$\begin{array}{c}\text { After bottling } \\
\mathbf{T}_{1}: \mathbf{A B}\end{array}$}} & \multicolumn{2}{|c|}{ Before bottling } & \multicolumn{2}{|c|}{ After bottling } & \multirow{2}{*}{\multicolumn{2}{|c|}{ Mean }} \\
\hline & & & & & & & & & \multicolumn{2}{|c|}{$\mathbf{T}_{4}: \mathbf{B B}$} & \multicolumn{2}{|c|}{$\mathrm{T}_{4}: \mathrm{AB}$} & & \\
\hline 0 & \multicolumn{2}{|c|}{13.03} & \multicolumn{2}{|c|}{13.03} & \multicolumn{2}{|c|}{14.13} & \multicolumn{2}{|c|}{14.13} & \multicolumn{2}{|c|}{16.27} & \multicolumn{2}{|c|}{16.27} & \multicolumn{2}{|c|}{14.48} \\
\hline 15 & \multicolumn{2}{|c|}{13.11} & \multicolumn{2}{|c|}{13.09} & \multicolumn{2}{|c|}{14.18} & \multicolumn{2}{|c|}{14.18} & 16 & & & & \multicolumn{2}{|c|}{14.53} \\
\hline 30 & \multicolumn{2}{|c|}{13.16} & \multicolumn{2}{|c|}{13.15} & & & 14. & & & & & & 14 & \\
\hline 45 & & & & & & & 14 & & & & & & 14 & \\
\hline 60 & 13 & & & & & & 14. & & & & & & 14 & \\
\hline 75 & & & & & & & 14 & & 16 & & & & & \\
\hline 90 & & & & & & & 14. & & & & & & 14 & \\
\hline Mean & 13 & & 13 & & & & 14 & & & & & & & \\
\hline Factors & $\begin{array}{r}\text { With/V } \\
\text { presel } \\
(\end{array}$ & $\begin{array}{l}\text { Iithout } \\
\text { vative } \\
\text { ) }\end{array}$ & Storag & period & $\begin{array}{r}\text { Th } \\
\text { proce }\end{array}$ & $\begin{array}{l}\text { mal } \\
\text { ing }(C)\end{array}$ & $A>$ & & $\mathbf{A}$ & & & & $A \times I$ & $\times C$ \\
\hline $\begin{array}{c}\mathrm{CD}(\mathrm{P} \leq 0.0 \\
5)\end{array}$ & 0 & & & & & & $\mathrm{~N}$ & & & & & & & \\
\hline $\mathrm{SE} \pm \mathrm{m}$ & 0 . & & 0 . & & & & 0. & & 0 . & & & & 0 . & 4 \\
\hline
\end{tabular}

$\mathrm{T}_{0}: \mathrm{BB}$ - (100\% carrot juice), thermal processing before bottling),

$\mathrm{T}_{4}: \mathrm{BB}$ - (carrot-beetroot-aonla-ginger, 50:45:2.5:2.5), thermal processing before bottling,

$\mathrm{T}_{1}: \mathrm{BB}$ - (carrot-beetroot-aonla-ginger, 80:15:2.5:2.5), thermal processing before bottling

$\mathrm{T}_{1}$ : $\mathrm{BB}$ - (carrot-beetroot-aonla-ginger, $80: 15: 2.5: 2.5$ ), thermal processing after bottling,

$\mathrm{T}_{0}$ : $\mathrm{BB}$ - (100\% carrot juice), thermal processing after bottling

$\mathrm{T}_{4}$ :BB- (carrot-beetroot-aonla-ginger, 50:45:2.5:2.5), thermal processing after bottling 
Table.4 Effect of different treatments (thermal processing with/without preservative) and storage periods on total antioxidant activity

(\% scavenging activity of DPPH) of carrot based RTS beverages stored at refrigeration temperature

\begin{tabular}{|c|c|c|c|c|c|c|c|c|c|c|c|c|c|c|}
\hline \multirow{3}{*}{$\begin{array}{l}\text { Storage } \\
\text { period } \\
\text { (Days) }\end{array}$} & \multicolumn{14}{|c|}{ Total antioxidant activity (\% scavenging activity of DPPH) } \\
\hline & \multicolumn{7}{|c|}{ With preservative } & \multicolumn{7}{|c|}{ Without Preservative } \\
\hline & $\mathbf{T}_{0}: \mathbf{B B}$ & $\mathbf{T}_{0}: \mathbf{A B}$ & $\mathbf{T}_{1}: \mathbf{B B}$ & $\mathrm{T}_{1}: \mathrm{AB}$ & $\mathbf{T}_{4}: \mathbf{B B}$ & $\mathbf{T}_{4}: \mathrm{AB}$ & Mean & $\mathbf{T}_{0}: \mathbf{B B}$ & $\mathbf{T}_{0}: \mathbf{A B}$ & $\mathbf{T}_{1}: \mathbf{B B}$ & $\mathrm{T}_{1}: \mathrm{AB}$ & $\mathbf{T}_{4}: \mathbf{B B}$ & $\mathbf{T}_{4}: \mathrm{AB}$ & Mean \\
\hline 0 & 30.93 & 32.25 & 37.93 & 39.55 & 47.04 & 49.29 & 39.50 & 30.15 & 31.62 & 37.60 & 39.23 & 46.71 & 48.96 & 39.04 \\
\hline 15 & 29.34 & 30.81 & 36.87 & 38.52 & 46.06 & 48.30 & 38.32 & 28.67 & 30.32 & 36.34 & 37.99 & 45.90 & 48.28 & 37.92 \\
\hline 30 & 28.30 & 30.80 & 35.69 & 37.35 & 44.93 & 47.10 & 37.36 & 26.70 & 28.59 & 34.95 & 36.61 & 44.21 & 46.72 & 36.30 \\
\hline 45 & 27.00 & 29.51 & 34.50 & 36.18 & 43.76 & 45.96 & 36.15 & 24.95 & 27.18 & 33.60 & 35.26 & 42.76 & 45.00 & 34.79 \\
\hline 60 & 25.72 & 28.26 & 33.30 & 35.00 & 42.59 & 44.79 & 34.94 & 22.97 & 25.43 & 32.03 & 34.13 & 41.53 & 43.73 & 33.31 \\
\hline 75 & 24.43 & 27.00 & 32.10 & 33.81 & 41.39 & 43.57 & 33.72 & 21.43 & 23.89 & 30.89 & 32.91 & 40.48 & 42.66 & 32.04 \\
\hline 90 & 23.22 & 26.08 & 30.88 & 32.58 & 40.17 & 42.35 & 32.55 & 20.23 & 22.46 & 29.35 & 31.49 & 38.80 & 41.28 & 30.60 \\
\hline Mean & 26.99 & 29.25 & 34.47 & 36.14 & 43.71 & 45.91 & 36.08 & 25.01 & 27.07 & 33.54 & 35.38 & 42.91 & 45.23 & 34.86 \\
\hline \multirow{3}{*}{$\begin{array}{l}\text { Storage } \\
\text { period } \\
\text { (Days) }\end{array}$} & \multicolumn{14}{|c|}{ Thermally processed RTS beverages } \\
\hline & \multirow{2}{*}{\multicolumn{2}{|c|}{$\begin{array}{c}\text { Before bottling } \\
\mathrm{T}_{0}: \mathrm{BB}\end{array}$}} & \multirow{2}{*}{\multicolumn{2}{|c|}{$\begin{array}{c}\text { After bottling } \\
\mathbf{T}_{\mathbf{0}}: \mathrm{AB}\end{array}$}} & \multirow{2}{*}{\multicolumn{2}{|c|}{$\begin{array}{c}\text { Before bottling } \\
\mathrm{T}_{1}: \mathrm{BB}\end{array}$}} & \multicolumn{2}{|c|}{ After bottling } & \multicolumn{2}{|c|}{ Before bottling } & \multicolumn{2}{|c|}{ After bottling } & \multirow{2}{*}{\multicolumn{2}{|c|}{ Mean }} \\
\hline & & & & & & & \multicolumn{2}{|c|}{$\mathrm{T}_{1}: \mathrm{AB}$} & \multicolumn{2}{|c|}{$\mathbf{T}_{4}: \mathbf{B B}$} & \multicolumn{2}{|c|}{$\mathrm{T}_{4}: \mathrm{AB}$} & & \\
\hline 0 & \multicolumn{2}{|c|}{30.54} & \multicolumn{2}{|c|}{31.94} & \multicolumn{2}{|c|}{37.76} & \multirow{2}{*}{\multicolumn{2}{|c|}{$\begin{array}{l}39.39 \\
38.26\end{array}$}} & \multicolumn{2}{|c|}{46.87} & \multicolumn{2}{|c|}{49.12} & \multicolumn{2}{|c|}{39.27} \\
\hline 15 & \multicolumn{2}{|c|}{29.00} & \multicolumn{2}{|c|}{30.57} & \multicolumn{2}{|c|}{36.61} & & & 45 & & 48. & & \multicolumn{2}{|c|}{38.12} \\
\hline 30 & \multicolumn{2}{|c|}{27.50} & \multicolumn{2}{|c|}{29.70} & & 32 & 36 & & 44 & & 46. & & 36. & \\
\hline 45 & & 00 & & & & 05 & 35 & & 43 & & 45. & & 35. & \\
\hline 60 & & 34 & & & & 67 & 34 & & 42 & & 44. & & 34. & \\
\hline 75 & & 93 & & & & 50 & 33 & & 40 & & 43. & & 32. & \\
\hline 90 & & 73 & & & & 12 & 32 & & 39 & & 41. & & 31. & \\
\hline Mean & & 00 & & & & 00 & 35 & & 43 & & 45. & & & \\
\hline Factors & $\begin{array}{r}\text { With/I } \\
\text { prese }\end{array}$ & $\begin{array}{l}\text { Vithout } \\
\text { vative } \\
\text { ) }\end{array}$ & Storag & period & $\begin{array}{l}\text { The } \\
\text { proces }\end{array}$ & $\begin{array}{l}\text { ing }(C) \\
\text { ingl }\end{array}$ & A & & A> & & $\mathbf{B} \times$ & & $A \times B$ & \\
\hline $\begin{array}{c}\mathrm{CD}(\mathrm{P} \leq 0.0 \\
5)\end{array}$ & & & & & & 58 & $\mathrm{~N}$ & & 0. & & $\mathrm{~N}$ & & $\mathrm{~N}$ & \\
\hline $\mathrm{SE} \pm \mathrm{m}$ & 0. & & 0 . & & & 21 & 0. & & 0. & & 0.5 & & 0.7 & \\
\hline $\begin{array}{l}\text { :BB - (100\% } \\
4 \text { BB - (carrot- }\end{array}$ & & a-gingel & $x_{5}$ & therm & & & $\begin{array}{r}\mathrm{T}_{1}: \mathrm{BB}- \\
\mathrm{T}_{0}: \mathrm{B}\end{array}$ & - & & hern & 1- & & & \\
\hline
\end{tabular}


Table.5 Effect of different treatments (thermal processing with/without preservative) and storage periods on total antioxidant activity (\% scavenging activity of DPPH) of carrot based RTS beverages stored at ambient temperature

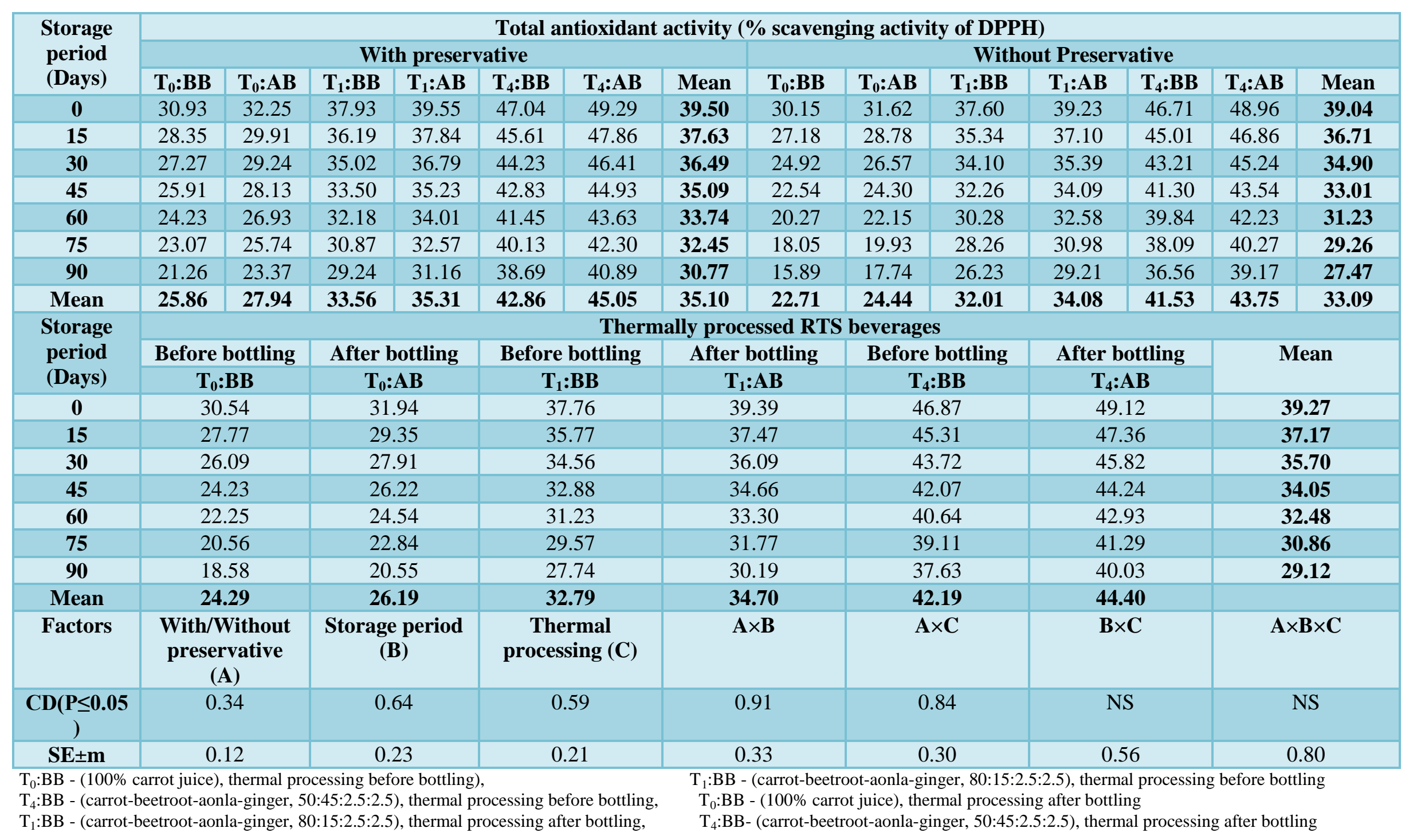


Fig.1 Flow chart for extraction of carrot, beetroot, ginger and aonla juices

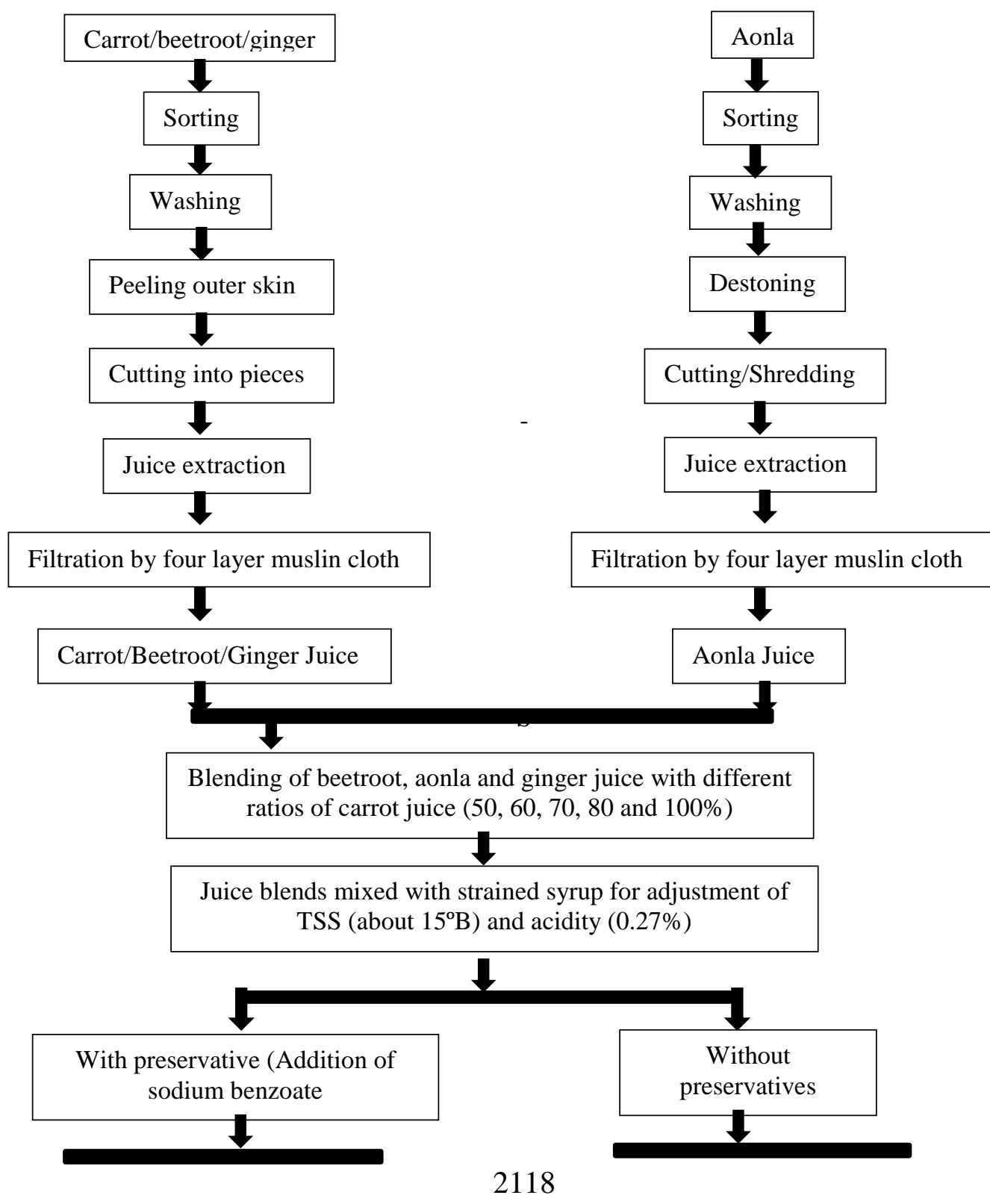




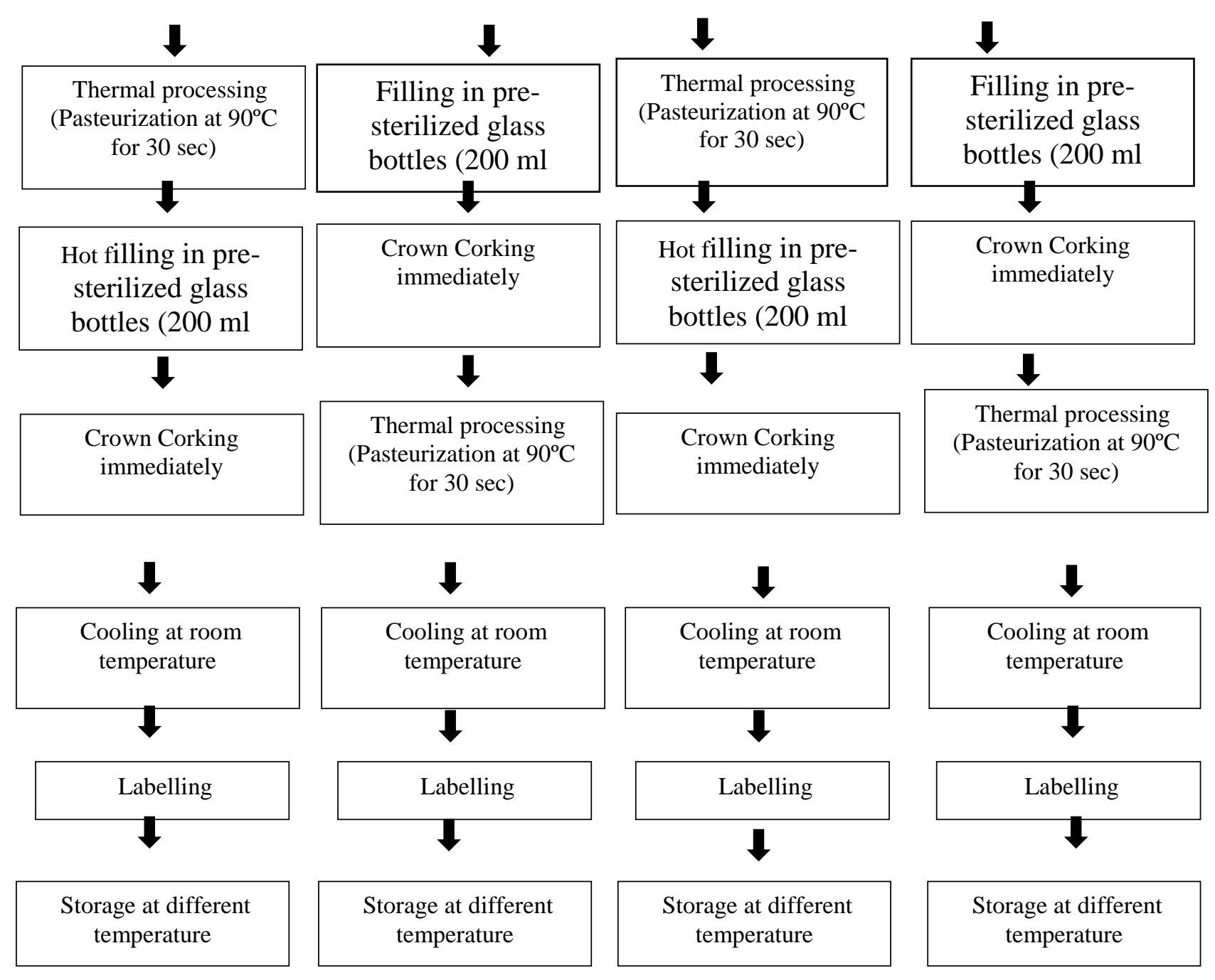


Fig.2 Effect of different treatments (thermal processing with/without preservative) and storage period on total antioxidant activity (\% scavenging activity of DPPH) of carrot based RTS beverage stored at refrigeration temperature
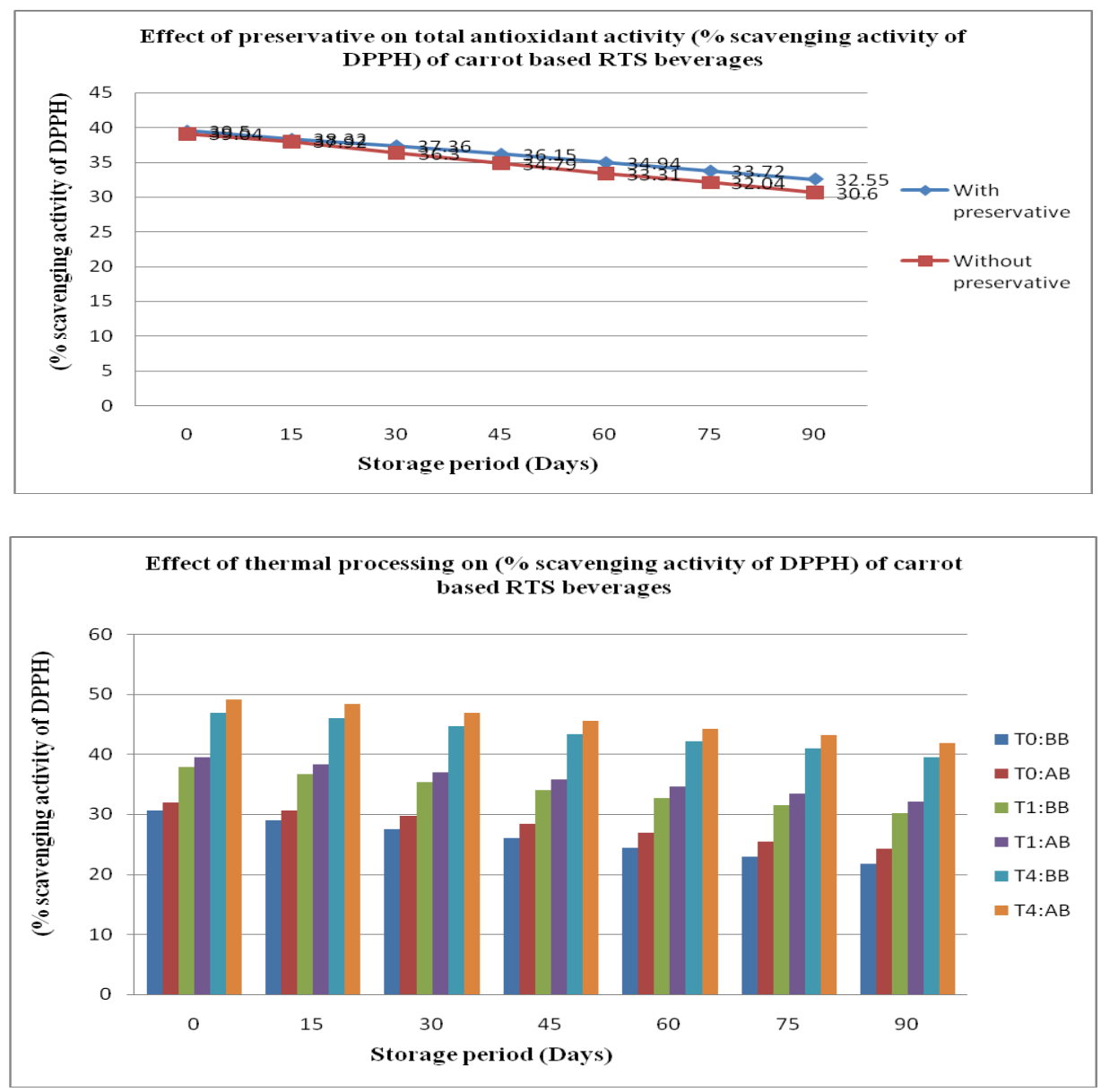

Fig.3 Effect of different treatments (thermal processing with/without preservative) and storage periods on total antioxidant activity (\% scavenging activity of DPPH) of carrot based RTS beverages stored at ambient temperature

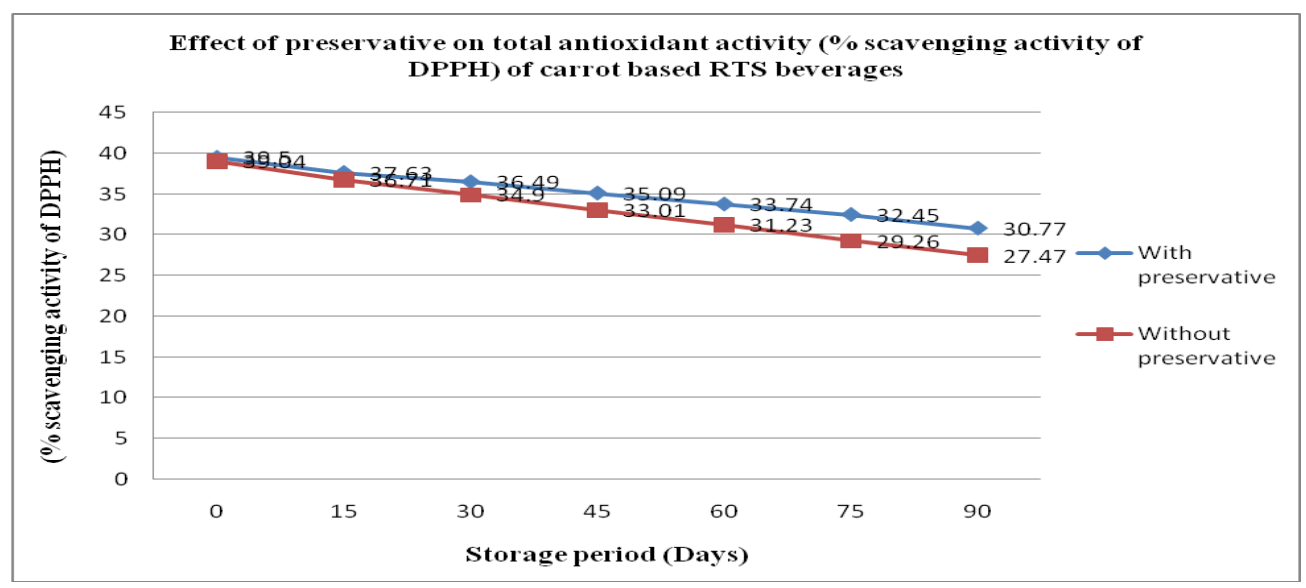




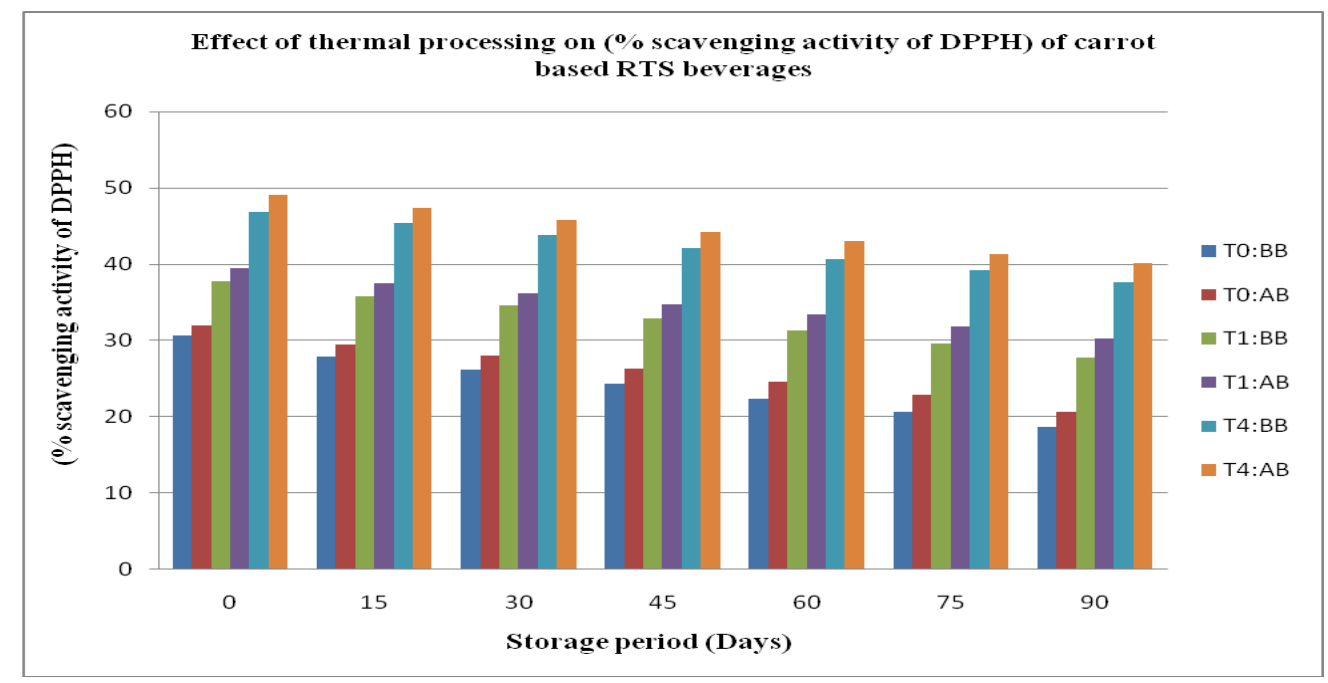

Total antioxidant activity (\% Scavenging activity)

The data revealed that the antioxidant activity of different treatments $\left(\mathrm{T}_{0}, \mathrm{~T}_{1}, \mathrm{~T}_{4}\right)$ of carrot based RTS beverages significantly and progressively decreased during three months of storage period at refrigeration temperature (Table.4). At 0 day, the average antioxidant activity was significantly decreased from 39.50 to $32.55 \%$ and 39.04 to $32.55 \%$ of carrot based RTS containing preservative and no preservative during storage. However, the two way interaction $(\mathrm{A} \times \mathrm{B})$ between with or without preservative and storage period was found to be non-significant. Irrespective of with or without preservative mean, the blended RTS beverages $\left(\mathrm{T}_{4}\right)$ had significantly higher antioxidant activity followed by $\left(\mathrm{T}_{1}\right)$ and minimum were recorded in $100 \%$ carrot based RTS beverages $\left(\mathrm{T}_{0}\right)$ during storage. The antioxidant activity was higher in thermally processed RTS beverages after bottling than before bottling up to three months of storage. The interaction $(\mathrm{B} \times \mathrm{C})$ between storage period and thermally processed RTS beverages was found non-significant. The antioxidant activity of RTS beverages was significantly affected by with or without preservative up to three months of storages and showed two way interaction $(\mathrm{A} \times \mathrm{C})$ between with or without preservative and thermally processed RTS beverages was significant. The various interactions $\mathrm{A} \times \mathrm{B}, \mathrm{B} \times \mathrm{C}, \mathrm{A} \times \mathrm{B} \times \mathrm{C}$ except $\mathrm{A} \times \mathrm{C}$ were found to be non-significant.

At ambient temperature, the results showed that the antioxidant activity of different treatments $\left(\mathrm{T}_{0}, \mathrm{~T}_{1}, \mathrm{~T}_{4}\right)$ of carrot based RTS beverages significantly and progressively decreased during three months of storage period. At 0 day, the average antioxidant activity of carrot based RTS beverages was significantly decreased (39.50 to $30.77 \%$ ) and (39.04 to 27.47\%) in treatments containing preservative and no preservative during three months of storage. The two way interaction $(\mathrm{A} \times \mathrm{B})$ between with or without preservative and storage period was found to be significant. Irrespective of with or without preservative mean, the blended RTS beverages $\left(T_{4}\right)$ had significantly higher antioxidant activity followed by $\left(\mathrm{T}_{1}\right)$ and minimum were recorded in 100\% carrot based RTS beverages $\left(\mathrm{T}_{0}\right)$ during storage. The antioxidant activity was higher in RTS beverages thermally processed after bottling than before bottling during storage. The interaction $(\mathrm{B} \times \mathrm{C})$ between storage period and thermally processed RTS beverages was found non-significant. The two way interaction $(\mathrm{A} \times \mathrm{C})$ between with or without preservative and thermally processed RTS beverages was found to be significant. The 
various interactions $\mathrm{A} \times \mathrm{B}, \mathrm{B} \times \mathrm{C}, \mathrm{A} \times \mathrm{B} \times \mathrm{C}$ except $A \times C$ were found to be non-significant at ambient temperature.

The antioxidant activities of carrot-beetrootaonla-ginger blended beverages were significantly higher than pure carrot juice beverage, possibly due to high antioxidant activity of beetroot-aonla and ginger juices. The decrease in antioxidant activities during storage was also observed in beverages developed from beetroot-passion (Kathiravan et al., 2015), carrot-mango (Saci et al., 2015), carrot-pineapple (Owolade et al., 2017), beetroot-orange (Porto et al., 2017) and banana-carrot-beetroot RTS drinks (Arora et al., 2019).Similarly, other researchers reported that the retention of higher antioxidant activity during storage in cucumber juice containing sodium benzoate (Kaur et al., 2014), carrot (Kaur and Aggarwal, 2015), red guava (Silva et al., 2016) and banana-carrot-beetroot RTS drinks (Arora et al., 2019).

On the basis of above results, it may be concluded that formulation of antioxidant rich mixed fruit and vegetable RTS beverages from carrot is able to satisfy consumer taste and preferences. The blending of carrotbeetroot-aonla-ginger is a product with an improved nutritional and increased shelf life quality. The RTS beverages treated with preservative was most effective than RTS beverages without preservative because it affects minimally TSS and antioxidant activity during storage. Results of the investigation concluded that RTS beverages were found superior under refrigeration conditions as compared to room temperature. Hence, these beverages could be a good addition to varieties of commercially produced therapeutic and non-alcoholic beverages available in stores and supermarkets.

\section{References}

AOAC, 2012. Official method of analysis. (19th edn.) The Association for Official Analysis in Chemistry, Rockwille, USA.

Arora, S., Siddiqui, S. and Gehlot, R. 2019. Physico-chemical and bioactive compound in carrot and beetroot juice. Asian Journal of Dairy and Food Research, 38(3): 252255.

Denny, A., Buttriss, J. 2007. Plant foods and health: focus on plant bioactive. European Food Information Resource (eurofir) Consortium. Funded under the EU 6th Framework Food Quality and Safety Thematic Priority. Contract FOOD-CT2005-513944.

Dias, J.S. 2012. Major classes of phytonutraceutical in vegetables and health benefits: a review. Journal of Nutritional Therapeutics, 1: 31-62.

Heber, D 2004. Vegetables, fruits and phytoestrogens in the prevention of diseases. Journal of Post graduate Medical, 50: 145-149.

Jan, A. and Masih, E. D. 2012. Development and Quality Evaluation of Pineapple Juice Blend with Carrot and Orange juice. International Journal of Scientific and Research Publications, 2(8): 1-8.

Jumde, A., Shukla, R. N. and Gousoddin, 2015. Development and chemical analysis of watermelon blends with beetroot juice during storage. International Journal of Science, Engineering and Technology, 3(4): 960-964.

Kathiravan, T., Nadanasabapathi, S. and Kumar, R. 2015. Pigments and antioxidant activity of optimized ready-to-drink (RTD) beetroot (Beta vulgaris L.) passion fruit (Passiflora edults var. Flavicarpa) juice blend. Croation Journal of Food Science and Technology, 7(1): 9-21.

Kaur, G. and Aggarwal, P. 2015. Effect of thermal processing and chemical preservative on the physico-chemical and phytochemical parameter of carrot juice. Asian Journal of Dairy and Food 
Research, 34(2): 146-150.

Kaur, G., Aggarwal, P. and Javed, M. 2014. Effect of chemical additives on the shelf life of cucumber juice. International Journal of Engineering Research Application, 4(1): 206-209.

Owolade, S.O., Akinrinola, A.O., Popoola, F.O., Aderibigbe, O.R., Ademoyegun, O.T. and Olabode, L.A. 2017. Study on physico-chemical properties, antioxidant activity and shelf stability of carrot (Daucus carota) and pineapple (Anana s comosus) juice blends. International Food Research Journal. 24(2): 534-540.

Panse, V.G and Sukhatme, P.V. 1985. Statistical method for agricultural workers. Indian Council of Agricultural Research, New Delhi.

Peter, C., Wootton, B., and Ryan, L. 2011. A beetroot juice shot is a significant and convenient source of bio accessible antioxidants. Journal of Functional Food, 3: 329- 334.

Pokharkar S. M. 2005. Development and performance evaluation of aonla shredding machine. Beverage and Food World, 32(3):52-53.

Porto, M. R. A., Okina, V. S., Pimentel, T. C. And Predencio, S. H. 2017. Physicochemical stability, antioxidant activity and acceptance of beet and orange mixed juice during refrigerated storage. Beverages, 3(3): 1-12.

Prasad, S. S., Kumar, S., Patel, K., Dumater, C., Vajpeyee, S. K. and Bhavsar, V. H. 2012. to investigate the action of ginger-juice Zingiber officinale roscoe (Zingiberaceae) on blood coagulation process. International Journal of Pharma Sciences and Research, 3(7): 407-415.

Saci, F., Meziant, L. and Louaileche, H. 2015. Effect of storage time and temperature on the health- promoting substances and antioxidant activity of two commercial fruit based - beverages. International Journal of Bioinformatics and Biomedical Engineering, 1(2): 118-122.

Shimada, K., Fujikawa, K., Yahara, K., and Nakamura, T. 1992. Antioxidative properties of xanthan on the antioxidation of soybean oil in cyclodextrin emulsion. Journal of Agricultural and Food Chemistry, 40: 945-948.

Silva, N.K.V.D., Sabino, L.B.D.S., Oliveira, L. S. D., Torres, L. B. D. V. and Sousa, P. H. M. D. 2016. Effect of food additives on the antioxidant properties and microbiological quality of red guava juice, Revista Ciencia Agronomica, 47(1): 77-85.

Singh, B. and Hatan, B. S. 2013. Optimization of osmotically dehydrated beetroot candy using response surface methodology. International Journal of Food and Nutritional Sciences, 2(1): 15-21.

USDA. 2012. Agriculture Handbook: Composition of Foods: vegetables and vegetables products, Raw, Processed and Prepared. U.S. Government Office, Washington, D. C.

Vali, L., Tefanovits-Banyai, E. and Szentmihalyi, K. 2007. Liver protecting effects of table beet (Beta vulgaris var.rubra) during is chemia-reperfusion. Nutrition, 23(2):172-178.

Yadav SS, Yadav PN. 2010. Studies on maturity of aonla (Emblica officinalis Gaertn.) fruits. Progressive Horticulture, 10(2):384-386.

Zhang, D. and Hamauzu, Y. 2004. Phenolic compounds and their antioxidant properties in different tissues of carrots (Daucus carotal.). Journal of Food, Agriculture, and Environment (JFAE),2: 95-100.

\section{How to cite this article:}

Laxmi Pandey, Renu Mogra and Arun Kumar. 2020. Effect of Preservative and Storage Temperatures on Total Soluble Solids and Antioxidant Activity of Carrot Based RTS Beverages. Int.J.Curr.Microbiol.App.Sci. 9(11): 2108-2123. doi: https://doi.org/10.20546/ijcmas.2020.911.251 